\title{
Integrated Mediation in the Court as a Hybrid Culture in Family Dispute Resolution in the Global Era
}

\author{
N Triana ${ }^{1}$, N Mukhtar ${ }^{2}$ \\ Institut Agama Islam negerti (IAIN) Purwokerto, Indonesia ${ }^{1,2}$ \\ \{triananita@ymail.com ${ }^{1}$; naqiyah.mukhtar@gmail.com $\left.{ }^{2}\right\}$
}

\begin{abstract}
Cultural globalization brought closer cross-cultural contacts accompanied by a reduction in the uniqueness of previously isolated communities. Globalization has also changed people's perspectives in the social system, economy, and even in legal cultures. The cultural shift takes place in family dispute resolution in which it has been deliberated to court through a divorce. A new model of family dispute resolution is needed, one which can bring together the local and modern two cultures. Using qualitative descriptive analysis, this research attempts to examine the values and strengths of the non-registration process. The results of the research show that a mediation model integrated into the court is exemplified by a family dispute resolution that can accommodate the two cultures in the community. This model of a hybrid culture in consensus-based dispute resolution could be integrated into the court system which is objective and binding. The integrated mediation in the court also represents a local and modern hybrid culture in terms of mediators. Deliberations or negotiations that are guided and organized by neutral and impartial mediators from the certified professionals could bring trust and resolution for the disputing parties.
\end{abstract}

Keywords: Legal Culture, Mediation, Family Disputes, Global Era

\section{Introduction}

Cultural globalization has increased contacts between cultures in which the uniqueness of previously isolated communities has been also reduced. Globalization has also changed the way individuals and groups behave towards their life, including their household, working, and legal patterns, thank the cultural influences from outside the country. In present Indonesia, the Muslim majority began to follow foreign cultural trends in any aspect of their life, including law. The key aspect of cross-cultural communication is interpersonal contact among the individuals or the groups [1].

Mass media has a very significant role for the entrance of foreign cultures in people's lives for whom it has different effects, both positive and negative. The relationships between two different societies will have a mutual influence. However, if the relationship is channelled through communication tools, there is a possibility that the influence will only come from one party, i.e. the ruling community who has power on the communication tools. When the influence of the community is accepted without coercive means, the result is called a demonstration effect [2]. The adaptation process of a new culture tends to be stronger and faster so that its traditional culture begins to be abandoned or possibly to be forgotten.

Legal culture can not be separated from the influence of the mass media. Legal culture is the whole factor that determines how the legal system has a logical place within the cultural framework of the public. The elements of legal culture that must be interpreted as people's attitudes toward the law and the legal system include their beliefs, values, ideas, and expectations. In other words, this is part of the general culture associated with the legal system [3].

The legal culture of family dispute resolution is not free from the influence of outside cultures. The settlement of family conflicts, that were previously resolved through deliberation between families, has now shifted into the court. News on divorce has now gained a spotlight in the media as the infotainment reporters consider it high selling news. This kind of news has also become a popular commodity among women and mothers. In the end, the resolution of divorce disputes does not belong only to the artists or socialites, but it has also an effect on the public in general. The data from the Religious Court shows that the divorce rate is increasing every year.

According to Marriage Law No.1/1974 and in Islamic teachings, the purpose of marriage is ideally to create a sakinah, mawaddah and warahmah family. It also serves as a means of worship to perfect the sunnah. Therefore, when a household can still manage the family problems, reconciliation is the best decision, while divorce could be the last option when keeping the marriage would only bring harm to both parties. 
Integrated mediation in the court aims to reconcile the disputing parties. This is different from adjudication, which means "examining and deciding cases." The decision on a case or dispute is not always the same as "resolving" or "solving' the case or dispute. A decision from the judge in adjudication is more likely depending on the wounds, such as resentment, hatred, hurt feelings, and so forth.

In adjudication, family conflicts are actually never resolved. Furthermore, dissatisfaction with the judges' decision has always the potential to cause new disputes or conflicts. Thus, in order to avoid deeper injuries or new disputes, it is necessary to change the orientation from "deciding a case" to "resolving a case". In a court case, what happened is that both parties in dispute are not only losing properties, but also brotherhood, a friendship between them.

Based on the above description, it is very interesting to examine how mediation is integrated into the court, as a hybrid culture of family dispute resolution.

\section{Method}

This research is non-doctrinal research with a qualitative descriptive analysis, which describes the values and strengths of non-law in the process of working the law [4]. The legal science approach is used to conduct textual studies of laws and policy regulations relating to mediation and marriage, while the social science approach in this research is in the domain of its methodology, namely to reveal external aspects outside the law, in this study These external factors are the cultural factors in resolving family conflicts.

\section{Result and Discussion}

\section{Mass Media and Cultural Shifts in the Global Era}

Advanced information technology leading to globalization are has a direct impact on civilization. The development of information technology is moving very rapidly, bringing with it positive and negative impacts on people's lives in all countries. Some called this development a "communication explosion". If globalization is defined as the development of human culture, the globalization of information and communication arises because of the development in electronic technology capable of supporting acceleration and quality improvement. Information is no longer limited by time and space.

Mass media influences people's lifestyles as presented by the media. Consciously or not, the public consumes it. Implicitly, the presence of mass media has given rise to a new culture that wants people to adapt to that culture. This culture is known as popular culture, which is not just a matter of dressing or hairstyle, but more than that it is also about the economy, social life, and also law. People's adjustment towards popular culture has caused social changes as a whole.

The way people behave to laws in a society is called a legal culture. Friedman [5] defined the term as an atmosphere of social thoughts and social forces that determine how the law is used, avoided or abused. Without legal culture, the legal system itself is helpless, like "a dead fish lying in a basket, not a living fish swimming in the sea. The cultural components, which consist of values and attitudes, influence the operation of law or what Friedman calls a legal culture. It is this legal culture that functions as a bridge that connects the rule of law with the legal behaviors of all the citizens.

Seidman said that the operation of the law is interrelated with other social problems. It means that law is not only a value system but also a sub-system of a larger social system, i.e. the society wherein the law is enforced [6]. The context of law as a system indicates that law should be interpreted comprehensively, not in a piecemeal and partial. The basic meaning of the system is always oriented to the goals of the larger system because of which the operation of the social system has something valuable.

The operation of marital laws in Indonesia is not only influenced by regulatory or legislative factors or by structures or institutions, but also by legal culture. Substantially, Law No. 1/1974 Article 1 regulates that: Marriage is an inner and outer bond between a man and a woman as husband and wife with the aim of forming a happy and eternal family (household) based on the Godhead of the Almighty. However, with the shifting culture of marriage law, the inner bond with God in marriages began to disappear. When problems and disputes arise in marriages, they ended up with divorce in court.

\section{Legal Culture of Family Dispute Settlement in Court}

Friedman said that "The Legal System Theory" consists of legal structure, a legal substance, and legal culture. He argued that substance and structure are the real components of a legal system. However, they serve only as a blueprint of legal design and they have not yet described the actual works of a legal machine. Thus, legal culture is ideas, attitudes, hopes, and opinions about law as the whole factor that determines how the legal system found its logical place. 
In the context of family conflict resolution, the community's legal culture in resolving family conflicts has been shifting to the court. This can be seen from the following data in two courts, i.e. the Purbalingga Religious Court and the Cilacap Court:

Table 1. Divorce Rate in Purbalingga Religious Court Class I-B

\begin{tabular}{|l|l|l|l|}
\hline Year & $\mathbf{2 0 1 7}$ & $\mathbf{2 0 1 8}$ & Until July 2019 \\
\hline Divorce (Talak) & 573 & 513 & 341 \\
\hline Divorce Lawsuit & 1.735 & 1.775 & 1.154 \\
\hline Total & $\mathbf{2 . 3 0 8}$ & $\mathbf{2 . 2 8 8}$ & $\mathbf{1 . 4 9 5}$ \\
\hline
\end{tabular}

Source: Registrar of the Purbalingga Religious Court

Table 2. Divorce Rate in Cilacap Religious Court Class I-A

\begin{tabular}{|l|l|l|l|}
\hline Tahun & $\mathbf{2 0 1 7}$ & $\mathbf{2 0 1 8}$ & Sampai juli tahun 2019 \\
\hline Divorce (Talak) & 1.784 & 1.686 & 1.105 \\
\hline Divorce Lawsuit & 3.870 & 4.323 & 2.763 \\
\hline Total & $\mathbf{5 . 6 5 4}$ & $\mathbf{6 . 0 0 9}$ & $\mathbf{3 . 8 6 8}$ \\
\hline
\end{tabular}

Source: Registrar of the Cilacap Religious Court

The Purbalingga Religious Court is a class I-B court, with an average divorce of 2,298 in the last two years, while the Cilacap Religious Court is class IA Court with an average of 5,832 in the last two years. From the above data, it can be inferred that the high divorce rate illustrates the settlement of family disputes in Indonesian society that has begun to shift to the Court.

Law and society are reciprocally related because the law as a means of regulating society is working within and carried out by the community. The relationship can be symbiotic and fitualistic, i.e. supporting the growth and upholding of the law or vice versa [7].

The settlement of family disputes in court hinders the purpose of marriage as a bond that must be endeavored to maintain. Divorce in court also often causes hostility in the future, which is certainly very detrimental to the children of the marriage. The legal culture of dispute resolution that ends in divorce at the court is inconsistent with the values of the Indonesian legal culture.

The Indonesian people actually have dispute resolution models that have been living in the Indonesian culture, i.e. consensus or agreement. This kind of dispute resolution model also exists in Islamic laws acculturated in Indonesian Muslim society, i.e. suluh (peace). The fusion of the teachings of dispute resolution in suluh (peace) with the culture of deliberation in customary laws can occur because of the universal values of Indonesian society that are familial (communal). This dispute resolution through deliberation is what we know as meditation.

Philosophically, mediation is based on Pancasila, which is a consensus that is contained in the fourth precepts. Pancasila is the foundation of the Indonesian nation-state. The foundation provides living space in all the Indonesian people. A very important foundation in Pancasila is a democracy based on deliberation. The power held firmly by the community through the basic fundamental and main pillars of deliberation, which are democratic processes within the institution.

Within a legal-formal perspective, mediation in court is a form of policy to integrate alternative (nonlitigation) dispute resolution processes into the judicial process (litigation) by optimizing more simpler, faster, and less costly mediation institutions. The Civil Procedural Law, both HIR and Rbg, with colonial nuance in Article $130 \mathrm{HIR} / 154 \mathrm{Rbg}$ has laid the basic concept of a peaceful institution in court for civil cases [8].

The Supreme Court has sought to optimize peace efforts in the resolution of disputes with mediation institutions which are part of the case resolution process in court. The definition of mediation contained in PERMA (Supreme Court Act) No.1/2016, is a way of resolving disputes through a negotiation process to obtain the agreement between the parties with the help of the mediator. This definition is not much different from the one given by the experts. However, PERMA No.1/2016 provides more emphasis on the role of the mediator in the mediation process. The mediators must be able to find alternatives to dispute resolution. If the disputing parties failed to find a solution for their dispute, the mediator must be able to provide alternative solutions to them based on agreement. This is the important role of a mediator [9].

According to Islamic laws, the resolution of conflicts in the household in the community can be sought by parties who are asked to be the mediators. The mediators are recommended coming from the closest family members or, in the case there is none, an hakam may be appointed. Hakam is obliged to reconcile the litigants. Islam teaches Muslims to resolve disputes that occur between them through peace or ishlah. Hakam is intermediary party. In Munjib dictionary, it is stated that arbitration can be exemplified by tahkhim, which derived from the word hakkama. Etymologically, tahkhim means to make someone as a deterrent in a dispute [10]. 
In general, tahkhim has the same meaning as arbitration known today [11], i.e. One or two persons appointed by the two parties to serve as a referee in order to settle their disputes peacefully. The appointed person is called hakam. Nowadays, the word hakam refers also to a peacemaker, namely someone sent by the husband and wife when there is a dispute between them without deciding who is right or wrong between them. Arbitration is currently better known as dispute resolution in the economic field, because article 5, Law No.30/1999 states that arbitration is a model of dispute resolution for economic and business cases. However, philosophically the appointment of referees is also very possible for the resolution of family disputes.

Hakam who comes from the husband's family or the wife's side is considered having the ability to reconcile and help to resolve the conflicts between them. Sura An-Nisa: 35 mentioned that the participation of the third parties or hakam in the resolution of marriage conflicts between husband and wife is imperative. The commentators provided an explanation of the terms and established a code of ethics for a hakam or mediator in conducting mediation. The Qur'anic verse said that hakam must be from the husband or wife, but in the case of syiqaqi the scholars disagree on who is suitable and appropriate to be a hakam or a mediator. Some scholars argued that the mediator must be a family member or a relative. Some others interpreted that a hakam can be an outsider or a professional as long as he or she meets the requirements of fairness and competence in putting forward the initial efforts of ishlah.

Sociologically, mediation is the legal culture of the Indonesian people. In Indonesia, the peaceful settlement of disputes has long been a common practice since a long time ago. This can be seen from the customary law according to which the leaders can serve as figures who seek to resolve disputes among their members. The settlement of family disputes should be attended by the disputing families while the customary leader or the elderls will act as a peacemaker, a mediator or a referee. The dispute resolution is nuanced with peace. However, a cultural shift has been inevitable where mass media has contributed to the bringing of the resolution of family disputes to the court in which to judging and determining who is wrong or right, or winner or loser is strongly emphasized.

\section{Hybrid Culture in the Legal Culture of Family Dispute Settlement through Mediation}

Legal norms should not be in conflict with the basic principle (i.e. Pancasila). Law, as a sub-system, is not the only system in society, which is independent, autonomous independent, but rather than other sub-systems. The legal consequences as part of other sub-systems must always take into account the social, cultural, family, environmental and economic systems in society.

The society has been always developing or changing because it is a natural phenomenon in society. Parson [12] said that every society is subject to the process of change in any aspects wherein every element of society contributes to the disintegration and change of society. The demands for social change have an impact on the existence of a legal system that has been in the foreground.

In fact, the legal system is not merely a set of static rules, but a reflection that is constantly changing and developing, especially in relation to the diversity of social characteristics that live in both traditional and modern societies, both rapid and slow changes. In line with the idea that law is a reflection of the diverse social characteristics, there is no law that does not change [13].

As long as the change in the law is able to respond and follow the rhythm of the living laws in society, the law will always be in harmony with people's lives. The law is actually like a living organism, as Von Savigny said, that will remain alive and develop along with the development of society, according to its own moral authority. In this case, the law must continue to function for the social order and benefits.

In fact, the law is not anti-change and functional to serve various interests, both for the individuals and the groups. The change in the law itself actually functions as a bridge between human desires by which anarchist, destructive, and chaotic conditions can subdue.

Therefore, legislation should produce laws that are clearly readable and reflective of social reality. The law should not only serve as a formalization and concretization of community behaviors in the form of a series of articles, but it should also capture the soul of the community (volkgeist). Therefore, it must take into account and analyze the social context where the law will be applied. The case is true since law must be in accordance with the community and vice versa. Law needs to adjust to the conditions of development of the community [14].

PERMA (Supreme Court Act) Number 1/2016 concerning mediation procedures in the court, is a rule that responds to social changes in the resolution of family disputes. The development of the legal culture in family dispute resolution through a divorce in court is difficult to achieve for in mass media divorce is not considered taboo. On the other hand, the high rate of divorce seems to damage the values of the substance contained in the legislation and noble values in the marriage that people believe since long ago. Mediation that is integrated in the court, as regulated in Perma Number 1/2016, is a dispute resolution model that can harmonize the two different cultures (hybrid culture), i.e. the culture of resolving family disputes through a divorce in the court which has a legal certainty and a model of dispute resolution through consensus-based on peace.

The first important thing in order to empower mediation in the court is to change the mindset of the people who have the power to impose laws and regulations. It should be emphasized that every problem or dispute 
concerning civil relations must be preceded by a peaceful settlement [15], i.e. mediation of deliberation for consensus as mandated by the Fourth Precepts of Pancasila ("Wisdom in Consultation/Representative").

People must be fully aware that mediation is a negotiation between two parties facilitated by a neutral and impartial mediator. It also means consultation with people who are believed to be able to unite the parties in dispute. This mediation should not be only inherent and taking place in the process of settling civil disputes in court as regulated in PERMA 1/2016. Rather, it can be initiated at any time and anywhere according to the volunteerism of the parties. The values of volunteerism must be instilled in the minds of the people so that the initiation of mediation is not only limited to the court.

The second important thing in order to empower meditation is to increase the competence of mediators. The mediator is not a profession that is born and controlled by traditional leaders or village elders or scholars. To be a reliable mediator, everyone needs to have the ability to organize and lead negotiations, to listen, to map the problems, and to communicate. Some professionals may have the talent to become reliable mediators, such as those working in the fields of psychology, family sociology, law, economics. Meanwhile, a good mediator is the one who is able to go out of the "legal glasses" that see things as black or white (true or false). Everyone can develop mediator skills with training and experience.

The Supreme Court, in collaboration with several educational institutions, conducts a certification of mediators to provide basic skills for mediators. The program of mediator certification is important to understand the basic principles, theories, and to develop mediation skills. In addition, the certified mediator has the privilege and recognition of the court for making a peace deed (acte van dading), a court decision that makes peace agreement as strong as the court's ruling.

From this point of view, it is clear that mediation integrated in the court in the settlement of family disputes really combines together two different cultures in society across the times. That is, local values are meeting with deliberations and professional mediators or even certified mediators born out of a modern culture that is professional, certain and objective in nature.

\section{Conclusion}

Family dispute resolution by divorce in court becomes a culture of family law in the global era. Mass media plays a major role in shifting the culture from the resolution of family disputes by deliberation and peace to a divorce court.

Mediation, which is integrated into the court, is an option that can accommodate two cultures that exist in societies, giving rise to a hybrid culture, i.e. the settlement of family disputes oriented to peace by a means of consensus (musyawarah). This new culture is in harmony with the court system that is objective, certain and coercive. In this new mediation model, mediation is led and organized by a neutral and impartial mediator who could be a professional, a certified mediator or someone that the parties in dispute have trust in him or her in solving their family problems.

\section{References}

[1] A. T. Turistiati, "Intercultural Communication Competence: Its Importance to Adaptation Strategy Towards People With Different Cultural Background," Ijtimai'yya, vol. 1, no. 1, pp. 63-78, 2016.

[2] D. Berry, Journalism, Ethics and Society. England: Ashgate Publishing Limited., 2008.

[3] I. P. M. Hadiarto, "PurbaPenguatan budaya hukum masyarakat untuk menghasilkan kewarganegaraan transformatif," J. Civ., vol. 14 Nomor 2, p. 147, 2017.

[4] S. Irianto, "Memperkenalkan Studi Sosiolegal dan Implikasi Metodologisnya, dalam Metode Penelitian Hukum, Konstelasi dan Refleksi. Editor Sulistyowati Irianto dan Sidharta," JHMP-FHUI, p. 177, 2009.

[5] L. Friedmann, The Legal System: A Social Science Perspective. New York: Russell SageFoundation, 1975.

[6] R. B. Seidman and W. J. Chambles, Law, Order, and Power, Printed in United States of America. Pubhlised Stimulant Costly in Canada Library of Congress Catalog Card No.78-111948, 2010.

[7] B. S. Turner, Religion and Modern Society: Citizenship, Secularization and the State. Cambridge University Press, 2011.

[8] R. W. Bintoro, "Kajian Ontologis Lembaga Mediasi di Pengadilan," J. Yuridika, vol. 32 Nomor 1, p. $141,2016$.

[9] A. Mardiah, "Penyelesaian Sengketa Melalui Mediasi Berdasarkan Perma No. 1 tahun 2008," Kanun J. Ilmu Huk., vol. Nomor 53, no. Mardian, p. 154, 2011.

[10] N. K. Dahlan, “Arbitration and Mediation Method Applied to Islamic Finance Conflicts in Malaysia," $J$. Soc. Sci. Res., vol. 6 Nomor 1, no. Malaysia, pp. 1151-1158, 2012.

[11] A. Arne Huzaimah, "Menelaah Pelaksanaan Pengangkatan Hakam Pada Perkara Syiqoq Di Pengadilan Agama Indonesia Dan Mahkamah Syar'iyah Malaysia," J. Kaji. Syari'ah Dan Masy., p. 17, 2019. 
[12] T. Parson, Societies Evolutionary and Comparative Perspective (Engliwood Clifts NJ Prentice Hall). 1966.

[13] F. Halim, "Hukum dan Perubahan Sosial,” J. Al-Daulah, vol. 4/No.1/201, p. 108, 2015.

[14] P. Nonet and P. Selznick, Hukum responsif pilihan di masa transisi, no. Jakarta. Perkumpulan Untuk Pembaharuan Hukum Berbasis Masyarakat dan Ekologis (Hu Ma), 2013.

[15] M. Galanter, “Justice in many Rooms: Courts, Private Ordering, and Indigenous LawThe," J. Leg. Plur. Unoff. Law, vol. Volume 13, no. 19, pp. 45-47, 2013. 